\title{
Flux of ammonium from surf-zone and nearshore sediments in Nahant Bay, Massachusetts, USA in relation to free-living Pilayella littoralis
}

\author{
A. Marshall Pregnall’, Steven L. Miller \\ Department of Botany, University of Massachusetts, Amherst, Massachusetts 01003, USA
}

\begin{abstract}
The availability of inorganic nitrogen in the surf-zone of Nahant Bay, Massachusetts, USA, was studied in relation to the distribution and decomposition of a free-living population of the filamentous brown alga Pilayella littoralis. Slight ammonium enrichment was evident in the surf zone of one beach location and in the immediate vicinity of a sewage treatment plant outfall. Profiles of sediment ammonium were determined over an annual cycle at 4 mid-intertidal beach sites. Most sites contained sediment ammonium from $0.05 \mathrm{to} 0.1 \mu \mathrm{mol} \mathrm{cm} \mathrm{cm}^{-3}$, while one site with chronic algal deposition and burial showed greatly elevated sediment ammonium levels ( $\leq 6 \mu \mathrm{mol} \mathrm{cm}{ }^{-3}$ ). Efflux of ammonium from deep and shallow subtidal sediments and from intertidal surf-zone sediments was typically $\leq 100 \mu \mathrm{mol} \mathrm{m} \mathrm{m}^{-2} \mathrm{~h}^{-1}$, except at the site with chronic algal burial and decomposition, where flux of ammonium ranged from 200 to $2000 \mu \mathrm{mol} \mathrm{m} \mathrm{m}^{-2} \mathrm{~h}^{1}$ Sediment concentrations and benthic flux of ammonium from sandy subtidal and surf-zone sediments are generally low in Nahant Bay; however, beaches with chronic deposition and burial of free-living $P$. littoralis have very high ammonium content and flux owing to the decomposition of algae that have effectively concentrated nitrogen from a much larger area of the bay.
\end{abstract}

\section{INTRODUCTION}

Sandy beaches are generally characterized by lower content of organic matter and nutrients than sheltered mudflats or subtidal sediments, owing to the high degree of sediment reworking and interstitial water percolation from waves and tides (Eagle 1983, Kaspar 1983, McLachlan 1983, Nowicki \& Nixon 1985). While substantial amounts of organic detritus may be cast upon beaches, rapid fragmentation and leaching generally prevent the long-term accumulation of nutrients within beach sediments (Koop et al. 1982, Pugh 1983, McLachlan \& McGwynne 1986), although distinct enrichment may occur when elevated inputs become chronic (Oliff et al. 1970). Because of the rapid regeneration of organic matter, nutrient inputs to the adjacent surf zone may be considerable even though concentrations often remain quite low (McLachlan 1980, 1982, McLachlan et al. 1981).

A free-living population of the filamentous brown

Present address: Biology Department, Vassar College, Poughkeepsie, New York 12601, USA alga Pilayella littoralis grows throughout the year in Nahant Bay, Massachusetts, USA, where it often accumulates in large surf-zone drifts (Wilce et al. 1982, Wilce \& Quinlan 1983). The presence of this algal population and the decomposition of cast algae in beach sediments have led to the popular suggestion that Nahant Bay has become eutrophied, perhaps through nutrient inputs from a sewage treatment plant outfall in the bay. Initial work on this question concluded that the outfall did not contribute sufficiently high amounts of nitrogen and phosphorus to be blamed as a point source of nutrients that could cause the buildup of biomass of the nuisance population of algae (Quinlan 1982, Quinlan et al. 1983). Furthermore, Quinlan (1982) suggested that nitrogen availability limits the productivity of free-living $P$. littoralis in Nahant Bay, after consideration of N:P ratios for the algae and for inorganic and total dissolved nutrients.

Since the free-living algae periodically and persistently accumulate in surf-zone drifts and are often stranded and resuspended by the tides, much of the nitrogen demand of the population must be met by what is available in the nearshore area. One potential 
pool of inorganic nitrogen is the interstitial pore water of beach sediments, where microbial decomposition of organic matter provides newly regenerated nutrients that can diffuse or percolate into the surf-zone waters (Koop et al. 1982, Pugh 1983). The observations that experimental organic matter inputs can result in higher interstitial ammonium concentrations and increased benthic flux (Kelly \& Nixon 1984, Kelly et al. 1985, Andersen 1986) suggest that the decomposition of buried Pilayella littoralis in Nahant Bay could provide local increases in surf-zone nutrient availability. The free-living algae drift suspended in the water column within the surf zone and just above the sediments throughout Nahant Bay, where they are in close proximity to the sediments and may readily exploit any benthic flux of inorganic nitrogen. Furthermore, since large amounts of $P$. littoralis become buried during spring beach accretion but do not appear to decompose fully until summer, ammonium regeneration and availability may vary seasonally.

In order to assess the availability of inorganic nitrogen to free-living Pilayella littoralis, we monitored levels of ammonium, nitrate and nitrite at nearshore and surfzone stations in Nahant Bay and measured sediment ammonium profiles at 4 beach sites at intervals through an annual cycle. Additionally we determined the flux of ammonium out of sediments at several intertidal, shallow subtidal and deep mid-bay locations.

\section{MATERIALS AND METHODS}

Study area. Nahant Bay is located northeast of Boston, Massachusetts, USA (Fig 1). The bay has the shape of an open circle, with a series of curving sandy beaches that are separated by rocky promontories. Wave energy dissipated against the gently sloping bottom at depth creates directional surge that tends to move the barely negatively buoyant Pilayella littoralis towards the beaches, where large clouds aggregate in the surf zone. Wind-driven circulation in the nearshore zone sporadically concentrates the algal clouds at the ends of several beaches. If currents carry the algae around one rocky promontory, they subsequently drift along the next beach and accumulate against the next promontory. Shifts in wind direction may reverse the direction of algal drift along the beaches or drive the algae out of the surf zone into the mid-bay region, where they again become influenced by wave motion along the bottom and tidal exchange of bay water. $P$. littoralis is chronically cast upon the beach and buried at little Nahant North (LNN) (Fig. 1), where sediment profiles in late spring reveal as many as a dozen distinct layers of algal deposition that may occupy as much as $10 \%$ of the sediment volume down to $0.5 \mathrm{~m}$. Algae are also cast at Lynn Shore Drive

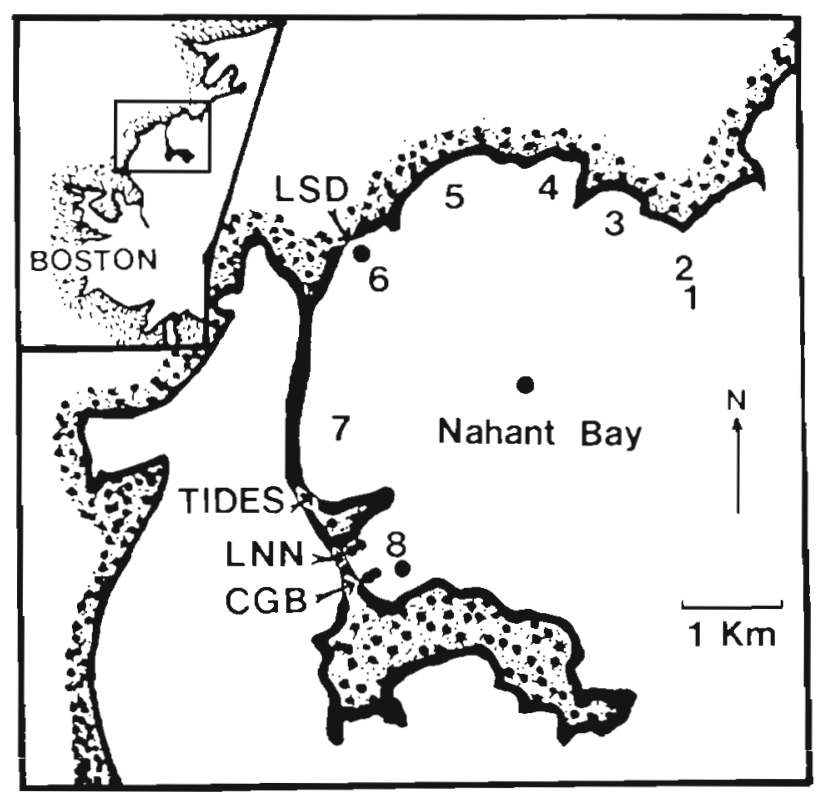

Fig. 1 Nahant Bay, Massachusetts, USA. Nearshore water collection stations are designated 1 through 8 ; Stns 1 and 2 are near the sewage outfall. The 4 beach stations for surf-zone water and sediment profile collections are designated LSD, TIDES, LNN and CGB. Benthic flux measurement stations are designated $(\bullet)$

(LSD) but appear to be buried more sporadically and much more shallowly (down to $10 \mathrm{~cm}$ ). Algae are infrequently found in the water or on the beach at the Coast Guard Beach (CGB) or at the TIDES site (Fig. 1) and are very rarely buried even to a shallow depth.

Water sampling. Water samples were collected at ca 2 mo intervals between December 1984 and November 1985 at 8 nearshore stations in Nahant Bay, including the region of the outfall (Fig. 1). Water samples were collected between May 1985 and March 1986 from 4 surf-zone stations along the beaches of Nahant Bay: LSD, TIDES, LNN and CGB (Fig. 1). At the nearshore stations water was collected from mid-depth with a Nansen bottle. Triplicate $25 \mathrm{ml}$ samples were filtered (Millipore Millex-PF $0.8 \mu \mathrm{m}$ and Millex-GS $0.22 \mu \mathrm{m}$ in series) and frozen immediately on dry ice. At the surfzone stations, triplicate samples were collected just beneath the surface by syringe and filtered as above.

Sediment ammonium profiles. At each of the 4 beach sites, vertical profiles of total sediment ammonium (interstitial plus exchangeable) at midintertidal elevations were measured. Sediments at depth were exposed by digging pits during low tide. Duplicate sediment samples $\left(25 \mathrm{~cm}^{3}\right)$ were taken by inserting tipless $50 \mathrm{~cm}^{3}$ syringes laterally into sediments at $10 \mathrm{~cm}$ intervals between the sediment surface and $50 \mathrm{~cm}$ depth. The sediment samples were extracted with $20 \mathrm{ml}$ of $1 \mathrm{M} \mathrm{KCl}$. After settling the supernatant was decanted, filtered 10.8 and $0.22 \mu \mathrm{m}$ in 
series), immediately frozen on dry ice, and kept frozen until analysis. Prior to measurement of ammonium concentration, samples were acidified with concentrated $\mathrm{HCl}$ and air bubbled to drive off hydrogen sulfide (Solorzano 1969). Dilutions were made with $3.0 \%$ (w:v) $\mathrm{NaCl}$ when concentrations were beyond the linear portion of the standard curve. Sediment ammonium concentrations have been corrected for dilutions during extraction and analysis.

Nutrient analyses. Ammonium concentrations were determined by a modified phenol-hypochlorite method (Solorzano 1969). Standards in both deionized distilled water and $3.0 \%$ (w:v) NaCl were linear through $60 \mu \mathrm{M}$, and the rhinimum detection limit averaged $<0.2 \mu \mathrm{M}$. Serial dilutions with $3.0 \% \mathrm{NaCl}$ were performed on samples having ammonium concentrations $>60 \mu M$. After October 1985 nitrate and nitrite were determined on a Technicon Autoanalyser using a modification of the procedure of Strickland \& Parsons (1968). At maximum sensitivity, the minimum detection level was $<0.2 \mu M$ nitrate and $<0.05 \mu M$ nitrite.

Benthic flux of inorganic nitrogen. Flux of ammonium was determined from August to November 1985 at 7 locations in Nahant Bay (Fig. 1), including an offshore station (14 $\mathrm{m}$ depth), a shallow subtidal station ( $3 \mathrm{~m}$ depth), and low- and mid-intertidal stations at 3 beach sites. From 3 to 8 flux chambers were placed at each station. Flux chambers were constructed of PVC pipe $(7.6 \mathrm{~cm}$ inner diameter $\times 30 \mathrm{~cm}$ length). Surf-zone turbulence prevented the use of broader and shallower chambers; strong wave scour often exposed 10 to $15 \mathrm{~cm}$ of the chamber body that had been driven into sediments. Chambers were placed into sediments to a depth of $20 \mathrm{~cm}$ and capped, isolating nearly $1 \mathrm{l}$ of sediments with an exposed area of $45.4 \mathrm{~cm}^{2}$. The change through time in nutrient concentration in the head space $(500 \mathrm{ml})$ was measured. At Time 0 and at $1 \mathrm{~h}$ intervals after placement, $30 \mathrm{ml}$ water samples were removed by syringe through serum stoppers in the chamber caps. Replacement water from the overlying water column was allowed to enter the headspace through fine-gauge syringe needles placed in serum stoppers to prevent the advection of pore water into the head space during sample withdrawal. Concurrently, duplicate ambient water column samples were taken above the chambers. Duplicate $250 \mathrm{ml}$ dark bottles were incubated in situ for the entire duration of the flux measurement to ascertain changes in nutrient concentrations owing to water column processes. Water samples were immediately filtered $(0.8$ and $0.22 \mu \mathrm{m}$ in series) and frozen on dry ice. Ammonium and nitrate were determined as above.

Changes in head space nutrient concentration were regressed against time, with correction for head space volume, sampling dilution, sediment surface area, and dark bottle changes, to derive rates of benthic nutrient flux. Incubations lasted from 4 (mid-intertidal) to 6.5 (shallow subtidal) hours. In several cases head space nutrient concentration increased, but linear regression analysis did not yield significant linear rates.

\section{RESULTS}

\section{Nearshore water collections}

Ammonium concentrations ranged from $<1$ to $7 \mu M$ over the duration of the study (Fig. 2). On 5 of 6 collection dates, samples in the vicinity of the outfall

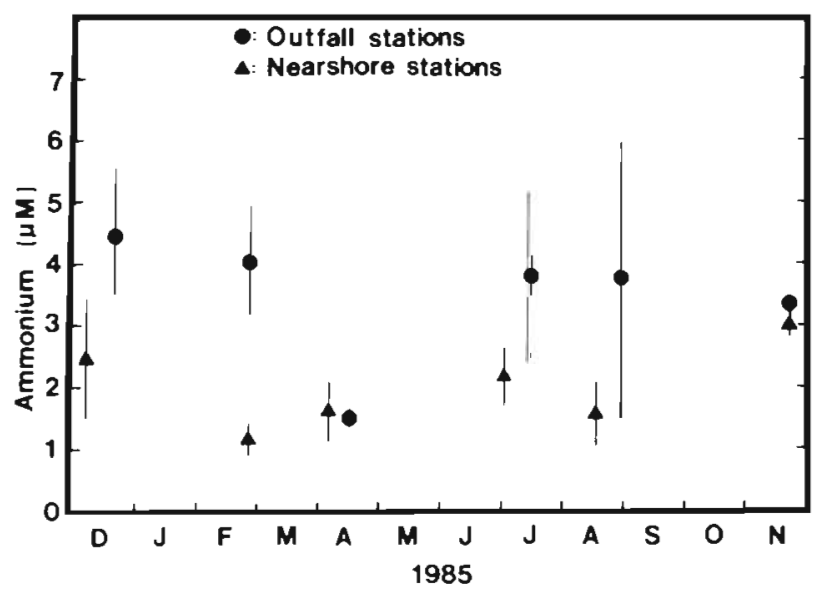

Fig. 2. Ammonium concentrations at nearshore stations. Values for Stns 1 and 2 (outfall) have been combined and are presented as mean $\pm 1 \mathrm{SE}$, as have values trom Stns 3 to 8

boil had the highest ammonium levels encountered (3.5 to $7.0 \mu \mathrm{M}$ ). The other nearshore stations in Nahant Bay had markedly lower ammonium concentrations (1 to 3 $\mu M)$ on all dates. Nitrate and nitrite analyses were not performed on the nearshore water collections.

\section{Surf-zone water collections}

Concentrations of nitrate at the surf-zone stations were variable and ranged from 0.5 to $4.0 \mu M$ (Fig. 3), while nitrite levels were quite low at all times $\quad<0.8$ $\mu M)$. Surf-zone ammonium levels were usually $<2 \mu M$ with one distinct exception. Water samples from LNN frequently had elevated concentrations of ammonium (5.9 to $12.0 \mu M)$, and on one date in the summer exhibited a mean concentration of $73 \mu \mathrm{M}$. We assume that the surf zone was enriched with interstitial drainage water on this occasion, for seepage water on the beach face smelled of decomposition products. 


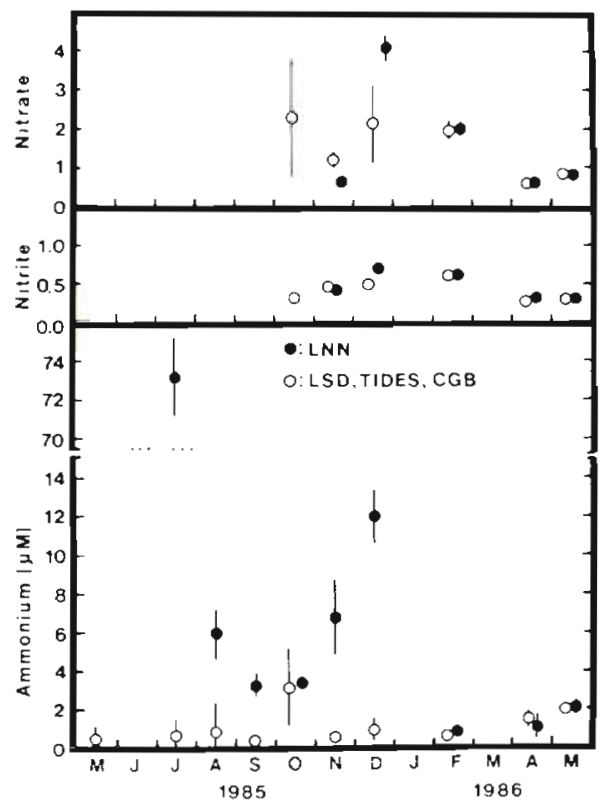

Fig. 3. Surf-zone concentrations of nitrate, nitrite, and ammonium at the 4 beach stations. Values for LSD, TIDES and $\mathrm{CGB}$ have been combined and are plotted as mean $\pm 1 \mathrm{SE}$ while values for LNN are plotted as mean $\pm 1 \mathrm{SD}$. Note the changes in scale for the different ions

\section{Sediment ammonium profiles}

Sediment ammonium concentrations (interstitial plus exchangeable) ranged from 0.05 to $0.10 \mu \mathrm{mol} \mathrm{cm} \mathrm{cm}^{-3}$ for 2 of the 4 locations sampled, at the TIDES and at CGB (Fig. 4). At beach station LSD, ammonium profiles were variable; levels comparable to those seen at TIDES and CGB were observed on 5 of the 7 collection dates, but very high levels $(1.5$ to $2 \mu \mathrm{mol} \mathrm{cm}-3)$ were found on 2 occasions. At LNN, extremely high concentrations of ammonium, up to $6 \mu \mathrm{mol} \mathrm{cm}^{-3}$, were observed on all collection dates. Concentrations of ammonium at the

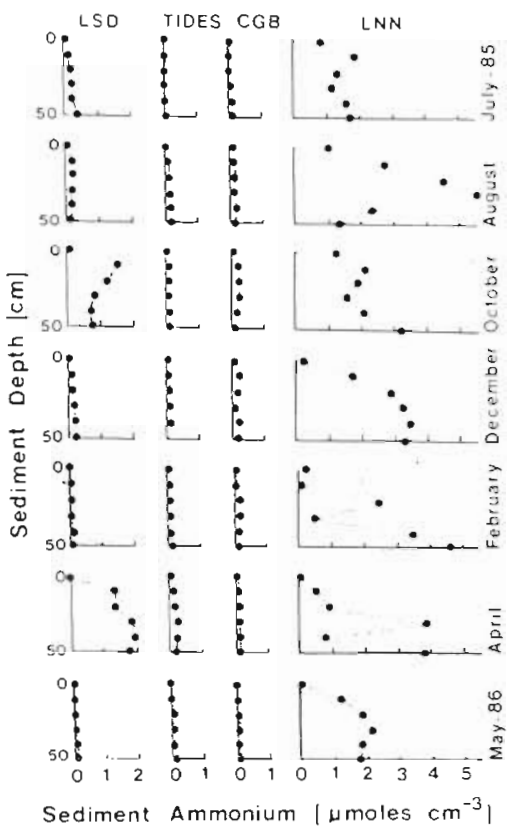

Fig. 4. Sediment ammonium (interstitial plus exchangeable) profiles at the 4 beach stations from July 1985 to May 1986. Mean range for all analyses (4 replicates per sample) was $21.8 \pm 16.2 \mathrm{nmol} \mathrm{cm}^{-3}$

sediment surface were about $1 \mu \mathrm{mol} \mathrm{cm} \mathrm{cm}^{-3}$ during sum mer and fall, but dropped below $0.2 \mu \mathrm{mol} \mathrm{cm}^{-3}$ during winter and spring

\section{Benthic nitrogen flux}

In the intertidal zone, ammonium flux from beaches with little or no algal deposition was usually less than our limit of detection (100 $\mu \mathrm{mol} \mathrm{NH}_{4}{ }^{+} \mathrm{m}^{-2} \mathrm{~h}^{-1}$ ) for incubations of short duration (Table 1). Longer incubations in the center of Nahant Bay and in the shallow subtidal zone off of CGB yielded similarly low rates of 30 to 110 umol $\mathrm{NH}_{4}{ }^{+} \mathrm{m}^{-2} \mathrm{~h}^{-1}$. In contrast the intertidal zone at

Table 1. Flux of inorganic nitrogen (mean $\pm 1 \mathrm{SD}$ ) from surf-zone and subtidal stations in Nahant Bay. Minimum detection limit for flux was determined by the duration of the incubations and the minimum concentration change that would have been necessary to cause a significant increase. Variation for nitrate analyses was less than for ammonium, resulting in a lower minimum detection limit

\begin{tabular}{|c|c|c|c|}
\hline Site & No. of chambers & Ion & Flux rate (umol $\mathrm{m}^{-2} \mathrm{~h}^{-1}$ ) \\
\hline LSD low intertidal & 6 & $\mathrm{NH}_{4}^{+}$ & $<100$ (below detection) \\
\hline LNN low intertidal & 3 & $\mathrm{NH}_{4}^{+}$ & $273+68$ \\
\hline LNN mid intertidal & 3 & $\mathrm{NH}_{4}^{+}$ & $1193=836$ \\
\hline \multirow[t]{2}{*}{$\mathrm{CGB}$ low intertidal } & 3 & $\mathrm{NH}_{4}^{+}$ & $<100$ (belurv detection) \\
\hline & 4 & $\mathrm{NO}_{3}^{-}$ & $-22 \pm 13$ \\
\hline CGB mid intertidal & 3 & $\mathrm{NH}_{4}^{-}$ & $<100$ (below detertion) \\
\hline \multirow[t]{2}{*}{ Little Nahant shallow subtidal ( $3 \mathrm{~m}$ ) } & 4 & $\mathrm{NH}_{4}^{+}$ & $95 \pm 14$ \\
\hline & 4 & $\mathrm{NO}_{3}{ }^{-}$ & $-15 \pm 6$ \\
\hline Nahant Bay center (14 m) & 8 & $\mathrm{NH}_{4}^{+}$ & $79 \pm 20$ \\
\hline
\end{tabular}


LNN exhibited flux rates of 205 to $2000 \mu \mathrm{mol}$ $\mathrm{NH}_{4}{ }^{+} \mathrm{m}^{-2} \mathrm{~h}^{-1}$. There appeared to be no relationship between temperature and flux for those sites that were visited more than once from August $\left(19^{\circ} \mathrm{C}\right)$ to November $\left(9^{\circ} \mathrm{C}\right)$.

On one occasion we determined the flux of nitrate from intertidal sediments at the CGB site and the shallow subtidal station (Table 1). All chambers yielded small but significant negative rates; that is, sediments appear to take up nitrate rather than release nitrate to the water column.

\section{DISCUSSION}

The continual reworking of beach sands by wave action usually lowers the sediment ammonium content relative to muddy shores or subtidal sediments, where deposition and decomposition of organic matter under more quiescent conditions permits the buildup of regenerated nutrients (Martens et al. 1978, Hopkinson \& Wetzel 1982, Eagle 1983, Kaspar 1983, Boynton \& Kemp 1985, Nowicki \& Nixon 1985, Pollehne 1986). The beaches of Nahant Bay are moderately exposed to wave action and consequently exhibit little buildup of organic matter or sediment ammonium with 2 important exceptions. The beach at Lynn Shore Drive (LSD) receives periodic deposition of free-living Pilayella littoralis, and occasionally the cast algae are buried in the beach sediments. The north end of Little Nahant beach (LNN) chronically receives algal deposition, sometimes to many $\mathrm{cm}$ depth. While accumulations of cast algae may begin to decompose on the beach surface, burial in sediments with subsequent decomposition also frequently occurs. During the spring period of beach accretion, many discrete layers of partially decomposed algae can be observed in sediment cores taken from LNN, but not from other beach sites that have been sampled.

A similar situation has been observed in a Florida lagoon, where decomposing drift algae greatly increased the interstitial ammonium content of underlying sediments for a brief period (Zimmerman \& Montgomery 1984). The condition in Nahant Bay is exceptional in that it occurs in a moderate-energy surf zone and that it appears to be a chronic situation at one site. Less dramatic pore water enrichment has been observed for sand trapped above a bedrock shelf following decomposition of cast algae on a South African beach (Koop et al. 1982). The observation that sediment ammonium levels fluctuate markedly at LSD suggests that normal beach reworking by surf and drainage of pore water during low tide can lower interstitial nutrient levels back to prior values over a matter of weeks if further algal burial and decomposition does not occur (see below). At LNN very high ammonium levels are observed right up to the sediment surface during the warm months of summer through early fall, while surface concentrations decline during colder winter and spring months. Even during the period of winter storms, there is a very large pool of inorganic nitrogen within these sediments that may become available to algae through sediment turnover and tidal drainage.

Our measurements of ammonium flux indicate that considerable ammonium is released from intertidal sediments at LNN where Pilayella littoralis is chronically deposited and buried (Table 1). Rates computed for the low intertidal zone at LNN are greater than most published rates for muddy sediments with high organic content (e.g. Pomroy et al. 1983, Boynton \& Kemp 1985 , Kaspar et al. 1985, Nowicki \& Nixon 1985). Flux measurements from beach sands without buried algae were below our detection limit for incubations of $<4 \mathrm{~h}(<100$ $\mu \mathrm{mol} \mathrm{NH}_{4}^{+} \mathrm{m}^{-2} \mathrm{~h}^{-1}$ ). We were unable to distinguish between the contributions of diffusive flux versus flux of ammonium through bioturbation or animal excretion. Estimation of diffusive flux from diagenetic models would be difficult, for we do not have fine-scale vertical profiles of sediment ammonium content. Aside from the flux that we did measure, we have ignored the contribution of percolation and flushing of interstitial water out of intertidal and subtidal sediments owing to tidal fluctuation and wave pumping, which could be considerable (Riedl 1971, Riedl et al. 1972, Johannes 1980, McLachlan 1982). Thus our estimates of ammonium flux are conservative by some unknown but potentially large degree.

Disregarding percolation or drainage, we can estimate ammonium turnover time for LNN. If we assume a mean concentration in the upper $20 \mathrm{~cm}$ of about $1.5 \mu \mathrm{mol} \mathrm{cm} \mathrm{cm}^{-3}$ for much of the year (Fig. 4), then there are ca $300 \mathrm{mmol} \mathrm{NH}_{4}{ }^{+} \mathrm{m}^{-2}$ available for flux in the upper $20 \mathrm{~cm}$. If we use a mean flux rate of about 730 $\mu \mathrm{mol} \mathrm{NH}_{4}{ }^{+} \mathrm{m}^{-2} \mathrm{~h}^{-1}$ (Table 1), it would require a minimum of $17 \mathrm{~d}$ to deplete the ammonium, or a turnover of approximately $0.058 \mathrm{~d}^{-1}$ It is unlikely that the high flux would continue as ammonium concentration dropped or that only the upper $20 \mathrm{~cm}$ are involved, but it does suggest that the infrequently observed peaks of sediment ammonium at LSD could be depleted within a month or two if further algal decomposition did not contribute to ammonium levels and if percolation efflux is of any importance.

Our measurements of benthic ammonium flux from sandy subtidal sediments agree quite well with those observed elsewhere (Nixon 1981, Hopkinson \& Wetzel 1982, Florek \& Rowe 1983, Pomroy et al. 1983, Boynton \& Kemp 1985, Kaspar et al. 1985, Nowicki \& Nixon 1985). The flux of nitrate from sandy subtidal sediments 
is variable, and may be negative (Florek \& Rowe 1983 , Kaspar et al. 1985, Nowicki \& Nixon 1985, Asmus 1986), as observed in Nahant Bay.

Periodic measurements of ammonium at nearshore stations in Nahant Bay indicate that slight enrichment appears to exist near the outfall boil (Fig. 2), but does not seem to extend beyond the immediate area. However, the contribution of ammonium to surf-zone waters by benthic flux at LNN may be sufficient to noticeably increase water column ammonium. If we assume the conservative estimate of flux used above $(730 \mu \mathrm{mol}$ $\mathrm{NH}_{4}{ }^{+} \mathrm{m}^{-2} \mathrm{~h}^{-1}$ ) over a $6 \mathrm{~h}$ period of tidal encroachment, $4380 \mu \mathrm{mol} \mathrm{m} \mathrm{m}^{-2}$ of ammonium would enter the water column. If the surf zone may be considered a wedgeshaped volume with a mean depth of about $1 \mathrm{~m}$ for a $2 \mathrm{~m}$ tidal range, then the ammonium would be diluted by $1000 \mathrm{l}$ of water over each $\mathrm{m}^{2}$, resulting in an increase of $4.38 \mu \mathrm{M}$ if no other processes such as algal uptake or nearshore mixing altered the situation. While this assumption is simplistic, the estimated change in ammonium approaches the difference observed between LNN and other surf-zone locations in Nahant Bay (Fig. 3) and elsewhere (Lewin et al. 1975, Bolter et al. 1981). Greater flux of ammonium clearly occurs on some occasions, and drainage of pore water at low tide must rapidly increase surf-zone ammonium at LNN; thus, it is not surprising that even greater increases in surfzone ammonium occur despite potentially rapid algal uptake.

Free-living Pilayella littoralis persists throughout the year in Nahant Bay (Wilce et al. 1983). Our data indicate that there is variation in ammonium availability between locations and times within the bay. We may conceptually consider the situation at 2 extremes. On one hand, population growth and maintenance would be entirely dependent upon the flow of nitrogen through the bay from long-shore coastal circulation. Population size would fluctuate with and be restricted by available nitrogen in Massachusetts Bay waters. At the other extreme, we may consider Nahant Bay to be a closed system with regard to nutrients, and the algal population would be sustained by nutrients regenerated within sediments (McLachlan 1980). Changes in the rates of burial, regeneration and flux would alter the availability of nitrogen to drifting algae. Losses from the bay owing to denitrification might be matched by inputs from the sewage outfall. However, since the distribution of free-living $P$. littoralis appears to be governed by chance fluctuations in wind direction and wave strength, the true situation must be a modified combination of the 2 scenarios, which will vary spatially and temporally in relative importance. Algae drifting offshore will be more dependent upon coastal circulation and open-water nutrient concentrations, while surf-zone algae will encounter the isolated reg- ions of high benthic flux that seem to result from algal burial and decomposition.

We suggest that free-living Pilayella littoralis in Nahant Bay can scavenge nitrogen from the water column throughout the bay, transforming it to algal biomass. The aggregation of drifting algae in the surf zone by water circulation serves to concentrate nitrogen that was formerly diffuse. The deposition and burial of algal biomass temporarily removes nitrogen from the system, but decomposition within sediments and efflux to the water column return inorganic nitrogen to an area of high algal abundance. The delay between burial and efflux may vary seasonally with temperature and severity of wave action. Sediment temperature, oxygen availability from percolation or turbulence, and frequency of algal input influence the duration of elevated ammonium levels and the concomitant stench of algal decomposition products. We anticipate that removal of cast algae prior to burial will ameliorate the noxious conditions resulting from decomposition, but will not preclude the development of large surf-zone drifts of free-living $P$. littoralis. The ability of the alga to take up nitrogen at low concentration while drifting throughout the bay will permit regrowth of the population and subsequent accumulation along the beaches.

Acknowledgements. This research was funded by a grant from the State of Massachusetts Metropolitan District Commission to R. T Wilce of the University of Massachusetts at Amherst. We are grateful for the efforts and assistance of the skipper and crew of Northeastern University's RV 'The Baron IV' We thank Master Chief W. Nelson, US Coast Guard, Rtd, for permission to work out of the Nahant Coast Guard Recreational Facility. Finally, we appreciate the considerable laboratory and field assistance of $M$. Berman, T. L. Briggs, J. Costa, J. Curry, A. N. Davis, D. S. Hibbet, R. van Etten, and R. $\mathrm{T}$ Wilce.

\section{LITERATURE CITED}

Andersen, F. Ø. (1986). Influence of Spartina detritus enrichment on exchange of nutrients between sediment and water in an intertidal area of Bay of Fundy. Mar Ecol. Prog. Ser. 29: 7-14

Asmus, R. (1986). Nutrient flux in short-term enclosures of intertidal sand communities. Ophelia 26: 1-18

Bolter, M., Meyer-Reil, L.-A., Dawson, R., Liebezeit, G., Wolter, K., Szwerinski, H. (1981). Structure analysis of shallow water ecosystems: interaction of microbiological, chemical and physical characteristics measured in the overlying waters of sandy beach sediments. Estuar, coast. Shelf Sci. 13: $579-589$

Boynton, W. R., Kemp, W M. (1985). Nutrient regeneration and oxygen consumption by sediments along an estuarine salinity gradient. Mar. Ecol. Prog. Ser 23: 45-55

Eagle, G. A. (1983). The chemistry of sandy beach ecosystems - a review. In: Mclachlan, A., Erasmus, T (eds.) Sandy beaches as ecosystems. Junk. The Hague, p. 203-224

Florek, R. J., Rowe. G. T. (1983). Oxygen consumption and dissolved inorganic nutrient production in marine coastal 
and shelf sediments of the Middle Atlantic Bight. Int. Revue ges. Hydrobiol. 68: 73-112

Hopkinson, C. S., Wetzel, R. L. (1982). In situ measurements of nutrient and oxygen fluxes in a coastal marine benthic community. Mar Ecol. Prog. Ser 10: 29-35

Johannes, R. E. (1980). The ecological significance of the submarine discharge of groundwater. Mar. Ecol. Prog. Ser 3: $365-373$

Kaspar, H. F. (1983). Denitrification, nitrate reduction to ammonium, and inorganic nitrogen pools in intertidal sediments. Mar. Biol. 74: 133-139

Kaspar, H. F., Asher, R. A., Boyer, I. C. (1985). Microbial nitrogen transformations in sediments and inorganic nitrogen fluxes across the sediment/water interface on the South Island west coast, New Zealand. Estuar. coast. Shelf Sci. 21: 245-255

Kelly, J. R., Berounsky, V M., Nixon, S. W., Oviatt, C. A. (1985). Benthic-pelagic coupling and nutrient cycling across an experimental eutrophication gradient. Mar. Ecol. Prog. Ser. 26: 207-219

Kelly, J. R., Nixon, S. W. (1984). Experimental studies of the effect of organic deposition on the metabolism of a coastal marine bottom community. Mar. Ecol. Prog. Ser. 17: 157-169

Koop, K., Newell, R. C., Lucas, M. I. (1982). Microbial regeneration of nutrients from the decomposition of macrophyte debris on the shore. Mar. Ecol. Prog. Ser. 9: 91-96

Lewin, J., Hruby, T, Mackas, D. (1975). Blooms of surf-zone diatoms along the coast of the Olympic Peninsula, Washington. V. Environmental conditions associated with the blooms (1971 and 1972). Estuar. coast. mar. Sci. 3: 229-241

Martens, C. S., Berner, R. A., Rosenfeld, J. K. (1978). Interstitial water chemistry of anoxic Long Island Sound sediments. 2. Nutrient regeneration and phosphate removal. Limnol. Oceanogr 23: 605-617

McLachlan, A. (1980). Exposed sandy beaches as semienclosed ecosystems. Mar. environ. Res. 4: 59-63

McLachlan, A. (1982). A model for the estimation of water filtration and nutrient regeneration by exposed sandy beaches. Mar, environ. Res. 6: 37-47

McLachlan, A. (1983). Sandy beach ecology - a review. In: McLachlan, A., Erasmus, T. (eds.) Sandy beaches as ecosystems. Junk, The Hague, p. 321-380

McLachlan, A., Erasmus, T., Dye, A. H., Woolridge, T., Van der Horst, G., Rossouw, G., Lasiak, T A., McGwynne, L. (1981). Sandy beach energetics: an ecosystems approach towards a high energy interface. Estuar. coast. Shelf Sci. 13: $11-25$

McLachlan, A., McGwynne, L. (1986). Do sandy beaches accumulate nitrogen? Mar. Ecol. Prog. Ser. 34: 191-195
Nixon, S. W. (1981). Remineralization and nutrient cycling in coastal marine ecosystems. In: Nielson, B. J., Cronin, L. E (eds.) Estuaries and nutrients. Humana Press, Clifton, p. $111-138$

Nowicki, B. A., Nixon, S. W. (1985). Benthic nutrient remineralization in a coastal lagoon ecosystem. Estuaries 8: $182-190$

Oliff, W. D., Gardner, B. D., Turner, W. D., Sharp, J. B. (1970) The chemistry of the interstitial water as a measure of conditions in a sandy beach. Wat. Res. 4: 179-188

Pollehne, F. (1986). Benthic nutrient regeneration processes in different sediment types of Kiel Bight. Ophelia 26: 359-368

Pomroy, A. J., Joint, I. R., Clarke, K. R. (1983). Benthic nutrient flux in a shallow coastal environment. Oecologia (Berl.) 60 306-312

Pugh, K. B. (1983). Nutrient cycles in sandy beaches. In: McLachlan, A., Erasmus, T. (eds.) Sandy beaches as ecosystems. Junk, The Hague, p. 225-233

Quinlan, A. V. (1982). An ecodynamic analysis of algal blooms fouling Nahant Bay beaches. MIT-Sea Grant, Cambridge

Quinlan, A. V., Lewis, T., Hoyt, J. K. (1983). Fouling of the sandy beaches of Nahant Bay (Massachusetts, USA) by an abnormal free-living from of the macroalga Pilayella littoralis (Phaeophyta). I. Habitat characteristics. In: McLachlan, A., Erasmus, T (eds.) Sandy beaches as ecosystems. Junk, The Hague, p. 271-284

Riedl, R. J. (1971). How much seawater passes through sandy beaches? Int. Revue ges. Hydrobiol. 56: 923-946

Riedl, R. J., Huang, N., Machan, R. (1972). The subtidal pump: a mechanism of interstitial water exchange by wave action. Mar Biol. 13: 210-221

Solorzano, L. (1969). Determination of ammonia in natural waters by the phenol hypochlorite method. Limnol. Oceanogr 14: 799-801

Strickland, J. D. H., Parsons, T R. (1968). A practical handbook of seawater analysis. Bull. Fish. Res. Bd Can. 167

Wilce, R. T., Qinlan, A. V (1983). Fouling of the sandy beaches of Nahant Bay (Massachusetts, USA) by an abnormal free-living form of the macroalgae Pilayella littoralis (L.) Kjellm. (Phaeophyta). II. Population characteristics. In: McLachlan, A., Erasmus, T. (eds.) Sandy beaches as ecosystems. Junk, The Hague, p. 285-295

Wilce, R. T., Schneider, C. W., Quinlan, A. V., Vanden Bosch, K. (1982). The life history and morphology of free-living Pilayella littoralis (L.) Kjellm. (Ectocarpaceae, Ectocarpales) in Nahant Bay, Massachusetts. Phycologia 21. 336-354

Zimmerman, C. F., Montgomery, J. R. (1984). Effects of a decomposing drift algal mat on sediment pore water nutrient concentrations in a Florida seagrass bed. Mar Ecol. Prog. Ser. 19: 299-302 